\title{
Analysis of Indonesian Tourism Potential Through the Sustainable Tourism Perspective in the New Normal Era
}

\section{Muhammad Yamin}

International Relations Department Jenderal Soedirman University, Indonesia muhammad.yamin@unsoed.ac.id

\section{Arif Darmawan}

International Relations Department Jenderal Soedirman University, Indonesia arif.darmawan@unsoed.ac.id

\section{Slamet Rosyadi}

Public Administration Department Jenderal Soedirman University, Indonesia

slamet.rosyadi@unsoed.ac.id

Submitted: 1 December 2020; Revised: 25 March 2021; Accepted: 29 May 2021

\section{Check for updates}

\begin{abstract}
Abstrak
Artikel ini bertujuan untuk menggambarkan sejauh mana Indonesia dapat keluar dari "belitan" pandemi COVID-19, khususnya di sektor industri pariwisata. Tujuan lain dari penulisan artikel ini adalah untuk menganalisis peran pemerintah Indonesia dalam menggunakan istilah "normal baru" dan kaitannya dengan pariwisata berkelanjutan selama pandemi COVID-19 belum berakhir. Pariwisata saat pandemi COVID-19 menjadi fokus pembahasan artikel ini karena Pariwisata merupakan salah satu industri yang paling dirugikan oleh pandemi COVID-19. Secara global kerugian pariwisata dunia mencapai US \$22 miliar. Angka ini akan terus meningkat selama pandemi ini tidak dapat dikendalikan melalui vaksin dan obat-obatan. Tak terkecuali Indonesia yang kehilangan pendapatan asli negaranya dari sektor ini mencapai puluhan triliun rupiah hanya dalam waktu empat bulan sejak WHO mengumumkan COVID-19 sebagai pandemi global. Situasi normal baru dalam kondisi pandemi COVID-19 yang masih berlangsung merupakan peluang sekaligus tantangan bagi dunia pariwisata pada umumnya dan pariwisata Indonesia pada khususnya. Perubahan gaya hidup dan kebiasaan masyarakat dalam berwisata secara langsung maupun tidak telah "menghantam" sangat keras industri ini, tidak dapat dipungkiri, mengaktifkan kembali kegiatan industri pariwisata memang memiliki resiko yang cukup besar namun di sisi lain banyak sektor industri pariwisata yang bergantung pada kehidupan masyarakat. Strategi Cleanliness, Health, Safety, Environment Sustainability (CHSE) yang dilakukan oleh pemerintah Indonesia merupakan salah satu upaya untuk kembali menggerakkan sektor pariwisata Indonesia di tengah pandemi COVID-19, sekaligus peluang untuk menerapkan tiga prinsip utama pariwisata berkelanjutan di Indonesia. era normal baru, yaitu melibatkan sektor sosial dalam keterlibatan kebijakan, menjaga keberlanjutan sumber daya alam, dan menjadikan pembangunan berkelanjutan sebagai sinonim dari pertumbuhan ekonomi.
\end{abstract}

Kata Kunci: Pariwisata, COVID-19, New Normal, CHSE.

\begin{abstract}
This article is part of an international relations study conducted by the authors. This study aims to illustrate the extent to which Indonesia can get out of the "entanglement" of the COVID-19 pandemic, especially in the tourism industry sector. Another purpose of writing this article is to analyze the Indonesian government's role in using the term "new normal" and its relation to sustainable tourism during the COVID-19 pandemic has not ended. Tourism during the COVID-19 pandemic is the focus of the discussion of this article because it is one of the industries most harmed by this pandemic. Globally the loss of world tourism reaches US\$22 billion. This figure will continue to increase as long as this pandemic cannot be controlled through vaccines and drugs. No exception for Indonesia, which lost the country's original income from this sector, reaching tens of trillions of rupiah in just four months since WHO announced COVID-19 as a global pandemic. The new normal situation during the ongoing COVID-19 pandemic is an opportunity as well as a challenge for world tourism in general and Indonesian tourism in particular. The change in lifestyle and habits of the community in traveling directly or indirectly has "hit" this industry very hard. Undeniably, reactivating tourism industry activities do have considerable risk, but on the other hand, many sectors depend on this industry. Cleanliness, Health, Safety, Environment Sustainability (CHSE) strategy conducted by the Indonesian government is one of the efforts in re-mobilizing Indonesia's tourism sector amid the COVID-19 pandemic, as well as the opportunity to apply three main principles of sustainable tourism in the new normal era, namely involving the social sector in policy engagement, maintaining the sustainability of natural resources and making sustainable development a synonym of economic growth. Keywords: Tourism, COVID-19, New Normal, CHSE.
\end{abstract}




\section{INTRODUCTION}

The tourism industry that can contribute more than 1.5 billion dollars (UNWTO, 2020) globally has no less than 50 million jobs $(\mathrm{BBC}, 2020)$ that can provide welfare for millions of families worldwide. Tourism industry growth has also increased $4 \%$ from the previous year (UNWTO, 2020) and can contribute about $6.4 \%$ to the world economy (Lew, 2011). Until finally, the COVID-19 pandemic changed many things, especially in the tourism industry.

COVID-19 pandemic has changed not only various human activities around the world but also the way people view to do social activities, trade, and travel, especially about the sustainability of the tourism industry in the future. Data show that the tourism industry has 900 million activities per year worldwide, and tourism is always related to nature, making it a major threat to biodiversity and natural resources worldwide. Therefore, necessary efforts are needed to make tourism more sustainable for all layers and levels, such as large international tour agencies to small tourism business owners or individuals. The challenge for sustainable tourism development is maximizing the positive impact of tourism, improving and channeling its benefits properly, and avoiding negative impacts. Besides, it refers to the differences in natural resources, culture, and economy of tourism affecting various international organizations that have made definitions, principles, charters, codes, and criteria for sustainability in tourism (International Labour Organization, 2012).

The concept of sustainable tourism as an indicator of the tourism industry's success has been applied by almost all countries making tourism a vital sector globally, including Indonesia. The sustainable tourism program has also been implemented by the Ministry of Tourism of the Republic of Indonesia. One example is the Indonesian Sustainable Tourism Award (ISTA), an award from the Ministry of Tourism and Creative Economic (Kemenparekraf) for destinations that have implemented a sustainable tourism system. This ISTA event has been held by the Ministry of Parliament in 2017 and is open to all tourism managers. This program has attracted many tourism managers and fostered sustainable tourism motivation in Indonesia (Ministry of Tourism Republic of Indonesia, 2017).

In its development, people began to look for responsible entertainment, namely alternative or sustainable forms of tourism such as nature-based tourism, ecotourism, and cultural tourism. Sustainable tourism is becoming more popular that some people mention that so-called "alternatives" will become "mainstream" at any given time (Arida, 2014). So, this sector needs better innovation to become more beneficial tourism and have a positive impact. The goal of sustainability advocates in tourism is to introduce and promote concepts in research and practice to help preserve environmental and cultural goals and provide the tourism industry a safer future. This goal is also reflected in Indonesia's tourism policy, where sustainable tourism is one of the desired destinations. It is believed that this concept provides positive consequences to the goal in terms of environmental protection and tourism resources and the opportunity to develop the economic prosperity of the community, which is then associated with poverty alleviation (Junaidi, 2017).

This more responsible tourism, commonly referred to as sustainable tourism, is tourism that takes full account of sustainability for the present and future of economic, social, and environmental impacts, addressing the needs of visitors, industry, environment, and host communities. Thus, sustainable tourism should be optimized for the use of environmental resources, respect the host community and ensure a viable long-term economical operation, providing that benefit is distributed fairly among all stakeholders (Ministry of Tourism Republic of Indonesia, 2017).

Sustainable tourism, in general, has three dimensions, namely economic, environmental, and social. According to Choi and Sirakaya (2006), sustainable tourism's economic dimension means it does not damage the commercialized resources for tourist activities and is for the long term. The social dimension reduces socio-cultural divisions by maintaining balance and harmony between communities through cooperative initiatives and social networking efforts between local groups, requiring attention and emphasis on local 
community participation. Sustainable tourism management provides socio-economic benefits for the community. People around tourist sites participate in tourist activity because of economic motives (additional income and employment opportunities) (Tosun, 2000).

The three dimensions of sustainable tourism (economic, environmental, and social) are the main concerns related to the COVID-19 pandemic that is still ongoing today. In practice, the Indonesian government has made strategic steps in dealing with this pandemic, especially in the Indonesian tourism sector. These measures include applying the "new normal" rules and the CHSE strategy (Kemenparekraf, 2020). In the authors' view, implementing "new normal" and CHSE is an approach strongly related to sustainable tourism. This approach can be seen from the very close relationship between the dimensions of sustainable tourism (economic, environmental, and social), new normal activities, and CHSE itself.

\section{LITERATURE REVIEW}

The term sustainable has been on the agenda for various interests of the government, non-government, and private sectors for more than twenty years. Sustainable tourism development has been on the agenda for more than half of that period. As a concept, it has been widely discussed and debated in various academic literature. Many tourism industries have sought to operate the concept for some time. Among the debates are the benefits of sustainable tourism development, conflicts between stakeholders when tourism is developed, and balancing the need for ecological responsibility and economic reality as an ongoing struggle. However, many experts argued that no real effort would make changes in the tourism industry, and sustainable tourism development remains a complex issue (Mcdonald, 2020).

The next complexity in the operationalization of sustainability is considering and understanding the lifecycle concept, as conveyed by Butler (1980). When this concept is applied to 'sustainability,' several progressive stages occur, which eventually lead to decline or stagnation. This concept has been applied to alternative tourism, such as ecotourism, and several other fields in some tourism literature. Some of these sources state that this concept cannot go well during the development stage in practice. The life cycle concept can be developed and implemented on strategies and mitigation efforts to prevent stagnation (Mcdonald, 2020). The concept of sustainability is complex, and its application cannot be made quickly. Therefore it takes good cooperation and a holistic approach by various stakeholders involved in the tourism industry.

Even though tourism is not the main focus of Agenda 21, new opportunities and tourism can go hand in hand with the sustainable concept in the document. Mowforth and Munt (1998) showed that Agenda 21 explicitly states that tourism can offer sustainable development opportunities for specific communities, especially for those in vulnerable areas. The tourism impact on the environment began to be highlighted during this period when the sustainable concept and development began to be developed. In 1995, the World Travel and Tourism Council (WTTC) requested to make the travel and tourism industry a model of environmental improvement (Body \& Butler, 1996), and Agenda 21 for the travel and tourism industry began to be developed (Hardy, Beeton, \& Pearson, 2002; Mcdonald, 2020).

Sustainable development of tourism is a program prepared at a meeting in Rio De Janeiro, Brazil, in 1992, discussing environmental and development issues. The meeting produced the concept of sustainable development. This concept was created in 1987 through the World Commission on Environment and Development. The definition of sustainable development is a process of fulfilling the needs at this time by promising and maintaining the needs for the next generation (International Labour Organization, 2012).

The concept of sustainable tourism, introduced by the World Commission on Environment and development (WCAD in the Brundtland's Report in 1985), states that "sustainable development is a development that meets the needs of the present without compromising the ability of future generation to meet their own needs". From the statement, it is understood that sustainable development can be carried out by fulfilling today's needs and not neglecting future 
generations' ability to meet their needs. Similarly, the United Nations World Tourism Organization (UNWTO) has its definition: "Tourism that takes into full account the economic, social, and environmental impacts now and in the future, answering the needs of industry, environment and host communities" (UNWTO, 2005).

The World Tourism Organization (WTO) puts forward development principles that include ecological sustainability, social and cultural sustainability, and economic sustainability, both for current and future generations. Sustainable tourism means tourism that considers the current and future economic, social, and environmental impacts, addressing the needs of visitors, industry, the environment, and host communities. Thus, sustainable tourism should be optimized to use environmental resources, respect the host community and ensure a viable long-term economical operation, providing that benefits are distributed fairly among all stakeholders. The challenge of sustainable tourism development is to harness the positive impact of tourism, increase and channel benefits in the right direction, and avoid or reduce the adverse impact as far as possible. Referring to the differences in natural resources, culture and economy, tourism effects, various international organizations have developed definitions, principles, charters, codes, and criteria for sustainability in tourism (UNWTO, 2005).

According to the International Ecotourism Society, sustainable tourism has three main components called the "Triple Bottom Line", which contain:

1. Environment-sustainable tourism should have a minor negative impact on natural resources to minimize damage to the environment (flora, fauna, habitat, water, life, marine resources, energy use, and contamination) and provide meaningful benefits to the environment gradually.

2. Social and Cultural-respect the original culture and local traditions and maintain its social structure. It should be in the planning and development, and the monitoring phase should involve all local stakeholders (individuals, local communities, stakeholders, and local government agencies) and certainly provide direction for tourism development.
3. The economy and local communities contribute to tourism development in the short and long term. This contribution can be very beneficial for local communities and the government. If business practices can do well, the economic improvement will occur on a sustainability basis because if it is not, the tourist attraction will not be adequately managed; it can even die (Stoddard, Pollard, \& Evans 2012).

Sustainable principles refer to environmental, economic, as well as social and cultural aspects, and the appropriate balance must be applied between these three aspects to ensure long-term tourism. Sustainable tourism should (UNWTO, 2005):

a. Utilize natural resources optimally and responsibly, maintain critical ecological processes, and preserve natural heritage and biodiversity.

b. Respect all existing cultural heritage and preserve it by taking good care of it, continuing to care for it, and contributing to inter-cultural understanding and tolerance.

c. Provide many economic benefits for the long term for the community, stakeholders, productive employment opportunities, and social services to accommodate the community and contribute to overcome poverty.

Stoddard et al. (2012) also stated that the concepts of the triple bottom line, sustainability, sustainable development, and sustainable tourism are closely related. According to them, sustainable tourism is the best way to preserve the "golden goose" of tourism because it can be used as a viable tool to improve the competitiveness of tourist destinations in the meantime. Tourism and sustainable development are the balance relationships between economic prosperity, environmental protection, and social justice.

Normative defining of sustainable tourism is currently getting a significant challenge from the ongoing COVID-19 pandemic. Three dimensions of sustainable tourism (environmental, socio-cultural, and economic) are exciting things to discuss in the future, especially related to changes and modernization due to the COVID-19 pandemic. 


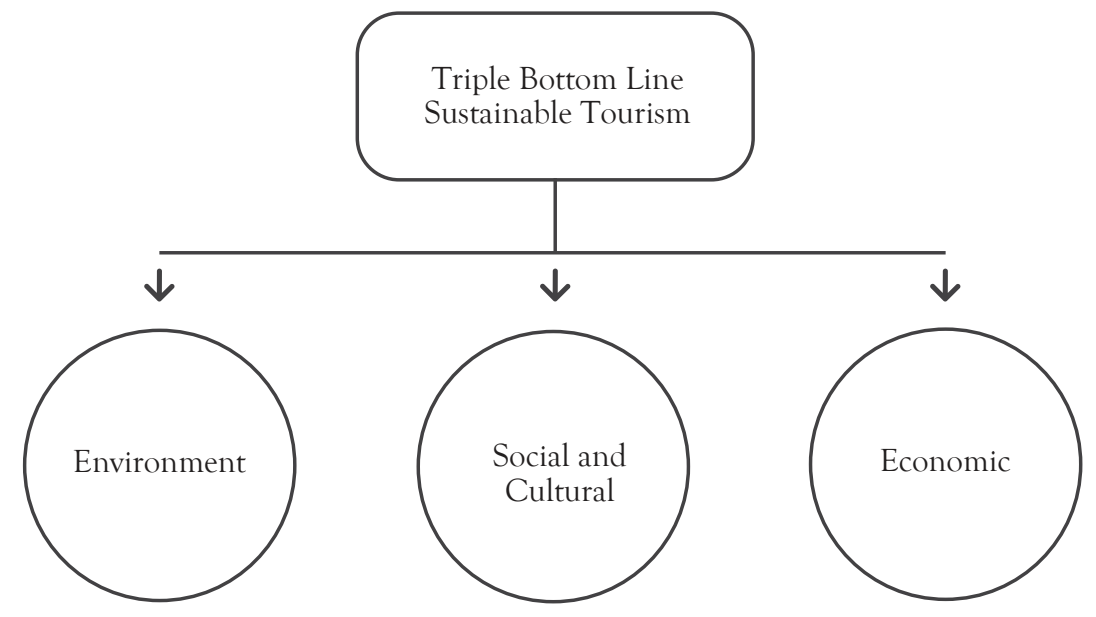

Figure 2. The Triple Bottom Line: A Framework for Sustainable Tourism Development (Stoddard et al. 2012)

\section{RESEARCH METHOD}

This research used a qualitative approach with a descriptive-analytical research method. Sukma Dinata (2006) in Ikbar (2014) mentioned that descriptive research aims to describe existing phenomena, both natural and human-made. The phenomenon can be objects of form, activities, characteristics, changes, relationships, similarities, and differences between phenomena. Descriptive research seeks to describe and interpret something, such as existing conditions or relationships, evolving opinions, ongoing processes, the consequences or effects that occur, or about its ongoing tendencies (Ikbar, 2014).

This paper utilized data processed from various sources as a research medium to describe the COVID-19 phenomenon as a global issue that poses a real threat to human safety, especially in the health sector. Moreover, this study also seeks to illustrate Indonesian government policy's critical role in reviving Indonesia's tourism sector from the COVID-19 pandemic.

\section{RESULT AND ANALYSIS}

Since the Indonesian government announced that COVID-19 cases had been found in Indonesia in March 2020, the spread of COVID-19 has occurred quickly. The Indonesian government has taken various initial measures and actions to prevent the spread of COVID-19, including by stopping learning and teaching activities in schools and colleges, closing places of worship, closing entertainment and tourist attractions, and restricting public travel. Various health campaigns such as the obligation to use masks, social distancing, and physical distancing continue to be voiced (DW, 2020).

The first three months (March-June 2020) quite effectively suppressed the human movement as the main factor of the spread of COVID-19. At that time, the Indonesian government formed a COVID-19 task force handling led directly by General Doni Munardo and the Head of the National Disaster Management Agency. It is the task, principal, and function of the agency in tackling natural and non-natural disasters. In this case, COVID-19 is categorized as a non-natural disaster included in the toxicology in coordination with the Ministry of Health, TNI, and Police (Ronald, 2020).

Although the first three months were quite effective in tackling the spread of COVID-19 nationally because almost all regions in Indonesia imposed Large-Scale Social Restrictions (PSBB) stipulated in Law No. 6 of 2018 on Health Quarantine, and Indonesia did not use the term "lockdown" like other countries around the world. However, it could not stop the spread of COVID-19 completely. The social, economic, and political impacts are stronger than health problems (Pranita, 2020). 


\section{THE COVID-19 PANDEMIC}

The pandemic began in December 2019 and was indicated to have originated in Wuhan City, Hubei Province, China, and spread quickly worldwide. Until this article was written, COVID-19 has spread to 215 countries worldwide (WHO, 2020). As an introduction, we need to know briefly what COVID-19 is. Corona Virus Disease 2019, abbreviated as COVID-19, is a type of virus that develops genetically similar to Severe Acute Respiratory (SARS) and Middle East Respiratory Syndrome (MERS). SARS was an epidemic in China in 2003, and MERS emerged in 2012 and developed into an epidemic in the Middle East (WHO, 2020).

COVID-19 is a highly contagious type of disease and has a long incubation period. The virus was initially identified in 27 cases and reported on December 31, 2019. The massive spread had made 60 million Wuhan City residents and several other cities in China impose a regional quarantine or lockdown on January 23, 2020. This quarantine has not even been applied to the previous virus epidemic (SARS) (Hong et al., 2020). According to ongoing research summarized by Chang, McAleer, \& Ramos (2020), COVID-19 is an easily contagious disease and has long-term consequences for infected individuals.

The history of the modern world, especially in the $21 \mathrm{st}$ century, has never recorded an event in which countries in the world restrict human movement and mobility, resulting in a global economic downturn due to the destruction of economic growth in all countries. World Wars I and II, Cold War, Gulf Wars I and II, 9/11, SARS and MERS, did not cause countries to collectively suffer such tremendous economic setbacks as caused by COVID-19 (Del Valle, 2020).

From the security approach, the COVID-19 pandemic is one part of the concept of human safety, especially in the health security sector. Rahmat (2015) stated that health has become one of the essential components in the emergence of various diseases in the history of humanity, such as bubonic plague, Spanish Flu, Bird Flu, HIV/AIDS, and others. Therefore, health security is understood as a threat arising from diseases caused by viruses or bacteria or the environment and arises from the absence of facilities and health insurance that cause death (Rahmat, 2015).

World health experts believe that the virus arises from extreme environmental damage worldwide (Sumani, 2020). Winarno (2011) in his book "Contemporary Global Issues" stated that most environmental disasters are now caused by human activity. The most destructive human activity is deforestation, caused by many complex factors. Farmland moving, palm oil plantations, and industrialization have caused significant environmental damage that plagues the world today.

We can see a close link between environmental damage and the emergence of various infectious diseases harmful to human health. Another result is the deterioration of the world economy due to the cessation of economic activity because most countries use a regional quarantine or lockdown approach to break the chain of the spread of this virus. According to health experts, this virus is easy to spread through mobilization and human activities (WHO, 2020), so emerge an appeal to practice "social distancing" and "physical distancing" campaigns in various countries (Milne \& Xie, 2020).

The economic impact from the cessation of mobility and economic activity in various countries makes many workers experience employment termination (layoffs). The slightest risk is "home" or non-employment. The cessation of the production sector caused considerable losses in almost all countries in the world affected by COVID-19. The last estuary in this economic calculation is the damage to the economy globally. Taking data from the World Bank, during the first three months (January-March 2020) the COVID-19 pandemic spread, the world economy's calculation was in the range of -34\% (World Bank, 2020).

Of the many economic sectors accumulated as global economic calculations, the tourism sector severely affected COVID-19 protesters. Since the COVID-19 pandemic, a significant decrease has occurred in all tourism activities globally (Metaxas \& Folinas, 2020). An article written by Metaxas and Folinas (2020) entitled "Tourism: The Great Patient of Coronavirus COVID-19" focuses explicitly on global tourism and how the sector is affected by the spread of the virus. However, the growth of tourism globally has been a lasting force and the most 
significant to move the world economy since the 1950s. Of the only 25 million human movements toward global tourism in the 1950s, then increased to 450 million in the 1990s and subsequently penetrated 1 billion human movements globally in 2010, until in 2018 the number of world tourist movements recorded 1.4 billion people, and in the United Nations, World Tourism Organization (UNWTO) tourism sector has contributed \$1.4 trillion and $7 \%$ of the value of goods and services worldwide (Metaxas \& Folinas, 2020).

The Organisation for Economic Cooperation and Development (OECD) report states that the COVID-19 pandemic has triggered an unprecedented crisis in the tourism economy and delivered direct and significant shocks to the sector. The OECD has revised the impact of COVID-19, which initially showed a $60 \%$ decrease in international tourism to $80 \%$ in 2020 , assuming that the economic recovery was delayed until December 2020. It is hoped that tourism in the European Union can recover first (UNWTO, 2020). Still, in the same report, the OECD also exemplifies that COVID-19 has devastated countries that expect a lot from the tourism industry. For example, tourism in Spain accounts for $11.8 \%$ of GDP while travel represents $52.3 \%$ of total service exports, in Mexico, these figures are $8.7 \%$ and $78.3 \%$, in Iceland $8.6 \%$ and $47.7 \%$, in Portugal $8.0 \%$ and $51.1 \%$, and in France $7.4 \%$ and $22.2 \%$ (UNWTO, 2020).

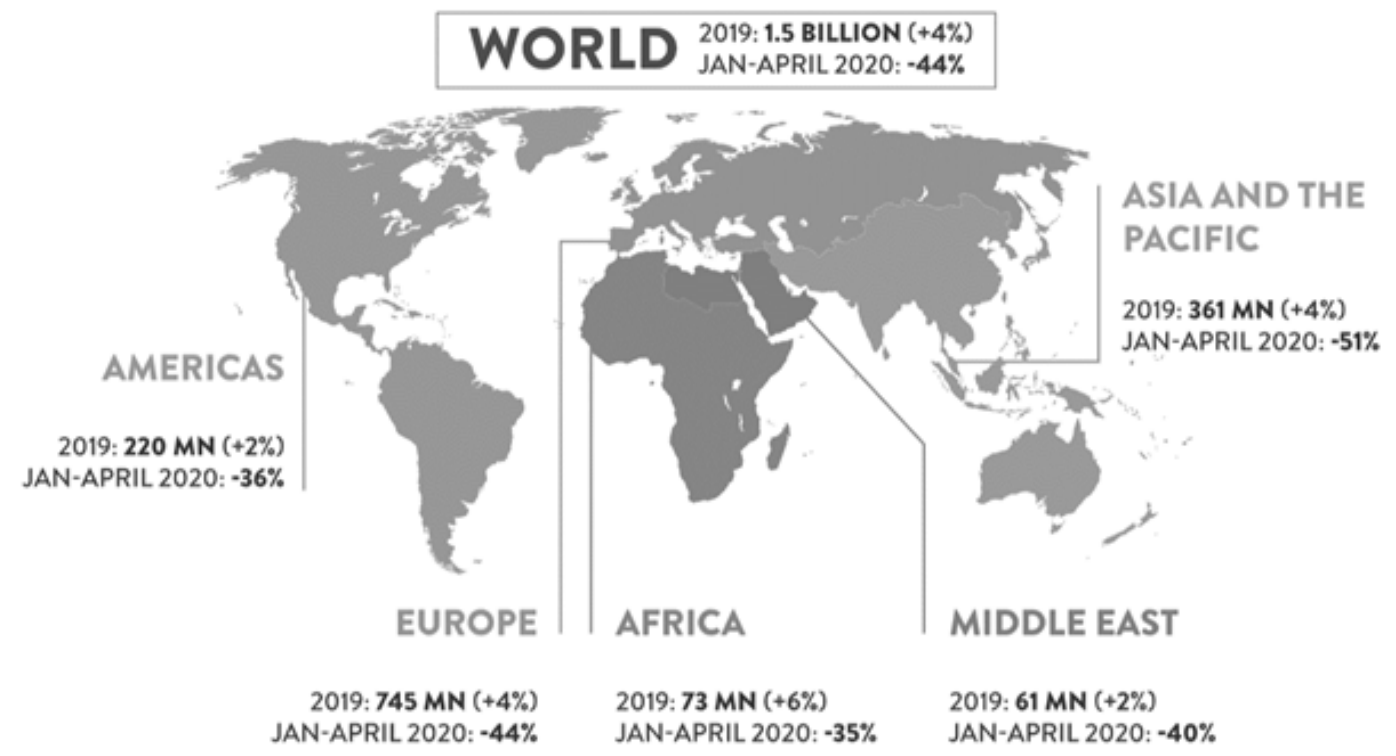

Figure 1. International Tourist Arrivals January-April 2020 (UNWTO, 2020)

Compared with the Spanish Flu in 1918-1919 during World War I claiming 675,000 victims in the United States and at least 50 million worldwide, the economy's impact was not so significant because economic destruction was only half the economy's level before World War. This impact was due to the large production to meet the needs in wartime. Economic growth was still recorded at a range of $9 \%$ in the United States. Furthermore, in the 21st century, the world experienced a SARS epidemic in 2003 that infected 29 countries on five continents. WHO has recorded 8,096 and 774 deaths, with a mortality rate of $9.6 \%$. The epidemic also devastated the tourism sector, where tourist movements decreased by $2.0 \%$ in 2003 and $9.0 \%$ in the Asian region. In Asia, there was a sharp decline in international tourism flows to Taiwan (-71.5\%), Singapore (-61.9\%), Hong Kong (-57.9), Malaysia (-51.6\%), and Japan (-25.7\%) (Del Valle, 2020). The latest data obtained by the authors from UNWTO indicate a remarkable decline in world tourism. As seen in the picture below, a decrease in world tourism activity is only recorded in January-April 2020, not for the entire year. 
From the picture above, we can see that the growth of world tourism in 2019 increased by $+4 \%$ or worth 1.5 billion dollars, while from January-April 2020, there has been a decrease of $-44 \%$ of the total world tourism. We can also see that America obtains a $+2 \%$ increase in 2019 and a $-36 \%$ decrease in January-April 2020. The same is true for Europe $(+4 \%$ in 2019 and $-44 \%$ in January-April2020), Africa ( $+6 \%$ in 2019 and $-35 \%$ in January-April2020), the Middle East (+2\% in 2019 and $-40 \%$ in January-April2020), and Asia-Pacific ( $+4 \%$ in 2019) (UNWTO, 2020).

As a country affected by the spread of COVID-19, Indonesia has also experienced a deep decline in domestic economic value. In the first quarter, Indonesia's economic growth was only around $2.97 \%$, and then in the second quarter, it experienced a profound contraction of $-5.32 \%$ (Badan Pusat Statistik, 2020). In the Indonesian tourism sector, the decline was profoundly due to the cessation of tourism activities and all supporting sectors such as aviation, the closure of tourist attractions, and the cessation of hotels and inns operations (Alam \& Belakang, 2020). Decreased revenue from Indonesia's tourism sector was more than $29 \%$ than the previous year and eliminated thousands of jobs in this sector (Revindo, Sabrina, \& Sowwam, 2020).

After more than six months of experiencing a negative contraction of the world tourism economy sector, UNWTO and several countries are trying to revive the world of tourism to restore countries' economies and globally. Indonesia is not staying silent on this condition. It has prepared strategic measures to re-excite the tourism economy sector, discussed more deeply in the following analysis section.

\section{IMPACT OF COVID-19 ON THE INDONESIA'S TOURISM INDUSTRY}

Economic activities stopped or forced to stop because of the restrictions imposed by both the central and local government has resulted in many people who lost their jobs because many businesses are reducing employees or even closed. Moreover, after the initial three months of the Indonesian government's strict action in tackling COVID-19, the government began to feel that this action resulted in the deterioration of the economic sector on both micro and macro scales.

It started in July 2020; the Indonesian government began to loosen various community activities, especially related to community economic activities, expecting economic growth to return to its original state. Campaigns about adopting new habits or better known as "new normal", began to be launched. Industry sectors that for more than three months were forced to stop or work from home (WFH) slowly began to open, the public consumption sector such as malls, shopping centers, and some tourist attractions also reopened.

Indonesian tourism experts have predicted the tourism industry. I Dewa Gde Sugihamretha (2020), as the Main Planner at the Ministry of National Development Planning (Bappenas), stated that the impact of COVID-19 on the tourism industry is evident in the decrease in foreign tourist arrivals through massive cancellations and bookings. The decrease also occurred in the slowing mobility of Indonesians traveling who are worried about the transmission of COVID-19. Meanwhile, the decline in tourism and tourist tourism business will significantly impact the MSME sector and disrupt employment. Similar to what Sugihamretha (2020) said, Awirya (2020) also stated that as an industry based on people's mobility, the COVID-19 outbreak immediately hit the tourism industry. A large number of economic sectors in the tourism industry caused the decline of the tourism industry, not only limited to sectors related to tourist travel and accommodation. Several other sectors supporting tourism activities were also affected.

The Central Bureau of Statistics (BPS) recorded a decrease in foreign tourist visits to Indonesia in early 2020. During January 2020, foreign visits reached 1.27 million. It decreased by $7 \%$ compared to foreign tourist visits in December 2019 of 1.37 million. The decrease in the number of foreign tourist visits was mainly due to the outbreak of COVID-19 in the last week of January 2020 (Sugihamretha, 2020).

The decline in foreign tourist visits to Indonesia is also seen from guesthouses' data coming through the air entrance (airport). Compared to visits in December 
2019, the number of guesthouse visits to Indonesia through the air entrance in January 2020 decreased by $5.01 \%$. The occupancy rate of star classification hotels in Indonesia in January 2020 reached an average of $49.17 \%$ or a decrease of 2.30 points compared to the January 2019 TPK of $51.47 \%$. Similarly, compared to December 2019, TPK hotel star classification in January 2020 decreased by 10.22 points. The average length of stay of foreign and Indonesian guests in star classification hotels during January 2020 was recorded at 1.88 days, decreasing by 0.17 points than January 2019 (Sugihamretha, 2020).

Based on the Indonesian Hotel and Restaurant Association (PHRI) data, until April 2020, the Indonesian tourism industry's total losses reached $\mathrm{Rp}$ 85.7 trillion. Thousands of hotels and restaurants were forced to close, as were several airlines and tour operators suffered losses (DW, 2020). Based on data compiled by Bisnis.com (2020), other than Indonesia, at least ten countries in the world suffered considerable losses from the tourism sector, among others, United States (US\$ 30.71 million), Spain (US\$ 9.7 million), France (US\$ 8.8 million), Thailand (US\$ 7.82 million), Germany (US\$ 7.22), Italy (US\$ 6.2 million), United Kingdom (US\$ 5.82 million), Australia (US\$ 5.82 million), Japan (US\$ 5.43 million), and Hong Kong (US\$ 5 million) (Kusumawardhani, 2020).

\section{CHSE STRATEGY AS A "NEW NORMAL" EFFORT IN THE INDONESIA'S TOURISM SECTOR}

The Indonesian government has taken the first step in reducing losses in the tourism sector through the Ministry of Tourism and Creative Economy (Kemenparekraf), which provides some stimulus and technical guidance on health protocols in the Indonesian and tourism world. As conveyed by Fadjar Hutomo, Deputy for Industry and Investment of the Tourism and Creative Economy Agency (Kemenparekraf) and Director-General of Regional Financial Balance of the Ministry of Finance have prepared a grant (DW, 2020). Fadjar also explained that this grant would be used "to improve the implementation of CHSE to increase regional readiness and tourism industry in implementing health protocols." Tourism strategy creative expert, Taufan Rahmadi, appreciated the steps that the Ministry of Parliament has prepared to restore Indonesia's tourism sector amid the pandemic so far. Nevertheless, according to him, the policies prepared should reach tourism industry players evenly (DW, 2020).

In addition to preparing technical guidance and a standard operating procedure (SOP) in tackling the impact of COVID-19 in the tourism industry, the Minister of Tourism (Menparekraf/Head of Baparekraf) Wishnutama Kusubandio took concrete steps to save the Indonesian tourism industry by coordinating with several other ministries, including the government to provide incentives through discounts on air tickets between 30\% to $40 \%$ for ten domestic destinations from March to May 2020. The ten tourist destinations in question included Batam, Denpasar, Yogyakarta, Labuan Bajo, Lombok, Malang, Manado, Silangit, Tanjung Pinang, and Tanjung Pandan. Moreover, the airline also provided discounts for most domestic tourist destinations (BBC News Indonesia, 2020). While waiting for the policy, the Ministry of Parliament also prepared cooperation with the hotel chain to be converted into a residence for medical personnel and task forces in various regions (Mutiah, 2020).

Re-mobilizing Indonesia's tourism industry can be a perilous step in increasing the spread of COVID-19. On the other hand, reviving the tourism sector can save the economy of people who depend their lives on tourism activities. Therefore, very carefully, the Indonesian government began to develop a new adaptation readiness protocol (new standard) in the Indonesian tourism sector.

Based on UNWTO guidelines, countries relying on revenue through the tourism sector should develop a sustainable tourism vision. This guideline is essential because tourist destinations that develop this vision can continue despite challenges, not least during the pandemic. Sustainable tourism defines UNWTO as tourism that considers the current and future economic, social, and environmental impacts, meeting the needs of visitors, industry, the environment, and local 
communities. The UNWTO guide also encourages countries to focus on the local tourist market until they are fully open for the larger market, foreign tourists (DW, 2020).

New normal or new life order drafted by the government to overcome the economy due to the COVID-19 pandemic is being discussed among the public. President Joko Widodo has said that people must now prepare for the new normal to coexist with COVID-19. One of them is in the tourism sector that will enter the new normal by opening tourist destinations and enacting new standard particular protocols in the tourism sector. In this case, the Ministry of Tourism and Creative Economy has developed the Cleanliness, Health, and Safety (CHS) program as a new regular order in tourist destinations by involving tourism industry players and creative economy that tourism is expected to be productive and safe from COVID-19 (Nisa, 2020).

\section{E-TOURISM AS ONE OF INDONESIA'S TOURISM STRATEGIES IN THE FUTURE}

Many ways in optimizing the new normal in the world of tourism are through the digital world's role. With the COVID-19 pandemic, it is becoming increasingly clear that digitalization aspects are essential to be adapted in the tourism sector and not just a temporary phase that will gradually disappear as the new normal comes along. Also, this transformation emphasizes that the e-tourism 4.0 strategy relies heavily on the internet, infrastructure readiness, human resource responsiveness, and plenary collaboration with other stakeholders. For Wishnutama, Minister of Tourism and Creative Economic, people's habit of using online platforms during this pandemic can be an opportunity for tourism operators to explore the digital age's potential. "Likes and dislikes, inevitably, this digitalization era is accelerating rapidly, especially with this condition where all are forced to understand digital faster" (Safriana, 2020).

The internet and digitalization became a bridge that connects the impasse due to all sectors' rapid movement, including national tourism. During the pandemic, it is as if digitalization becomes an "escape" solely from the offline dimension and is a novelty in the tourism industry that may have escaped existing studies and planning. The "new" thing is the webinar, e-commerce, virtual tour, and platform that allows tourism operators to offer their products and services online. This new activity is not something new; it is just that there is a sharp spike influenced by Indonesian society that dominantly stays at home due to social distancing.

The e-tourism 4.0 map has begun to be intensively cheered in the Ministry of Tourism's era under the leadership of Arief Yahya. The plan is quite familiar and exciting, with comprehensive strategies that include strategic themes: Wonderful Indonesia Digital Tourism 4.0; Strategic Imperatives for Transforming Tourism HR to Win Global Competition in Industry 4.0; 5 Technology Enabler; 9 Key Initiatives for Discipline Executions; and Pentahelix Collaboration Approach. The collaboration of all strategies is expected to encourage e-tourism 4.0 Indonesia to become increasingly developed and known globally (Safriana, 2020).

As reported from the infographic databooks, the government's funding to cope with the tourism aspect is not fooling around. Its value is 3.8 trillion rupiahs with a spread of 3.3 trillion for hotel/restaurant tax compensation, 400 billion for ticket incentives for ten tourism destinations, and 100 billion for tourism grants. Indeed, it is hoped that this fund's uptake can be stimulus support, subsequent strategy, and measurable follow-up step.

Nevertheless, there are more important things than just preparing digitalization devices to address this new standard. Discipline is the key to the tourism world to face the new normal era after COVID-19. Discipline must be maintained by tourists and tourism industry players so that all health protocols are adhered to maintain everyone's safety and security. In addition to maintaining safety and security, self-discipline can avoid the worst possible risks, namely the Second Wave of COVID-19, because when a tourist destination has been opened, foreign and Indonesian tourists all remain at risk (Widodo, 2020). 


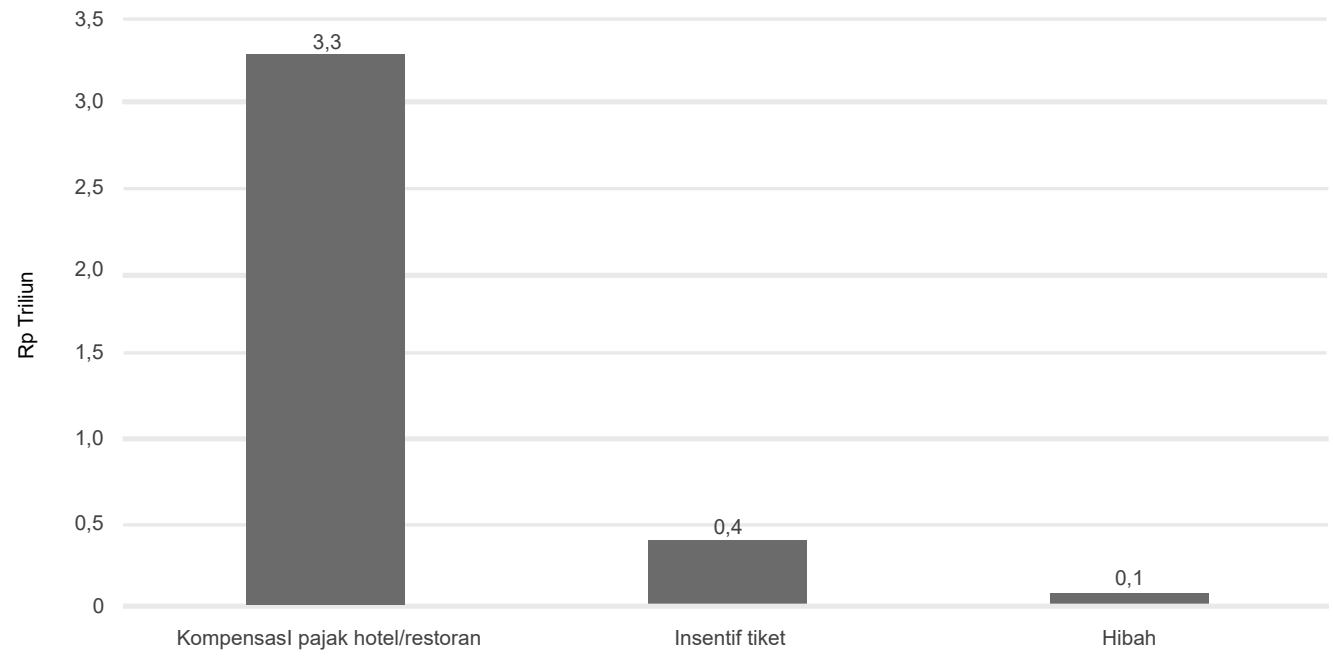

Figure 3. Budget details of the National Economic Recovery Program (PEN) of the tourism sector (Ministry of Finance, 2020)

\section{SUSTAINABLE TOURISM AFTER THE COVID-19 PANDEMIC}

Sustainable tourism is considered the most crucial aspect for developing the tourism sector in the new normal era after the COVID-19 pandemic. It will be an option and a consequence of the tourism development section. In the future, it must be strengthened, namely how tourism is centered on people-centered tourism or community-based tourism, which includes increasing product diversification, services following the needs of community behavior, and service patterns after efforts to increase the strength of local wisdom that eventually becomes a unique selling point. It must be maintained and managed to support human resources quality in the future. Likewise, domestic sustainability values, such as resilience and local wisdom, as well as balanced tourism, must deserve attention (Simatupang, 2021).

The three main dimensions in sustainable tourism (environmental, social-cultural, and economic) can be studied more deeply regarding tourism and the COVID-19 pandemic. In the environment research by Darma and Kristina (2020), the COVID-19 pandemic allows nature to rest for a while. The data in this study indicate real improvements in how air pollution in big cities starts to erode a little even though it cannot disappear at all. Nature-based tourism will become a new primadonna after the pandemic ends. Sustainable tourism will be an increasingly popular trend than mass tourism. It definitely will happen if supported by all relevant stakeholders in tourism (Darma \& Kristina, 2020).

The COVID-19 pandemic has had an impact on reducing air pollution in several major cities in Indonesia. Even in some international cities, especially cities with crowded activity conditions, there is a change in the air condition. Natural tourism is also affected by the decrease in travel activities in tourism wherever it is located. The cessation of tourism activities allows the natural ecosystem to recover and avoid human exploitation in the tourism industry, even though the recovery experienced cannot be felt instantly. It takes longer for the restoration of tourism nature (Darma \& Kristina, 2020).

On the socio-cultural side, the COVID-19 pandemic has changed people's lifestyles from conventional to digitalization. The government's social restrictions force people to implement a digital lifestyle to minimize activities causing crowds. As the authors mentioned above, the internet and the advancement of information technology in this pandemic era have drastically changed the world. From the beginning, the trend became a significant need. In other words, the COVID-19 pandemic has become the catalyst for socio-cultural change in the world community-no exception to the travel lifestyle seen in the sub-section after this. 
Information technology plays a vital role in the flow of information, communication in cyberspace, from positive to negative impacts. Changes in people's living order in the social and economic fields changed very quickly in recent years, especially in active communication in social media users, which conventionally occurred a sharp acceleration in active social communication through electronic media (Astuti, 2020).

In the economic sector, the Ministry of Parliament in the Strategic Plan 2020-2024 stated that tourism is experiencing a tremendous decline due to the decrease in international tourist arrivals due to this pandemic. This decline poses challenges for the ministry, especially in providing opportunities after the end of COVID-19. The Ministry of Parliament also stated that UNWTO's prediction of the tourism sector's contribution to GDP would experience a significant decrease. Tourism sector investment will also decline, along with the closure of hotels and some other amenities in tourism destinations. If the recovery of the post-pandemic tourism sector is unsuccessful, the unemployment rate will increase (Ministry of Tourism Republic of Indonesia, 2017).

However, this pandemic also poses other opportunities for the Ministry of Tourism and Creative Economic/Agency for Tourism and Creative Economic. The business model change from traditional tourism management to digital tourism management will allow the national tourism sector's maintenance and restoration. The digital-based creative economy sector can also be another solution in increasing tourism and creative economy contribution to GDP. The market segment's orientation will shift from foreign tourists to domestic tourists until international flights recover as the handling of the COVID-19 pandemic gets better than before. Therefore, a unique integrated strategy is needed in dealing with the impact of the COVID-19 pandemic on the tourism sector and the national creative economy, especially in the emergency response period in 2020 and recovery in 2021-2022 according to global conditions (Kemenparekraf, 2020).

\section{LIFESTYLE CHANGES IN FUTURE TRAVEL}

Research conducted by Sebastian Zenker \& Kock (2020) provides an interesting opinion that the COVID-19 pandemic will make some changes in tourism. Some of the arguments of the research results (Zenker \& Kock, 2020), among others, stated that first, there would be a change in looking at the image of world tourist destinations, especially some regions in Europe such as Austria, Italy, Spain, or the United States and China in Asia because the region has a high infection rate. This opinion has two consequences, namely the behavior of tourists who avoid such areas in the future, especially for tourist behaviors that fall into the vulnerable and at-risk category, or vice versa, the tone of groups of tourists who are morally moved to help economic recovery for areas affected by COVID-19. The second change is in tourist behavior. In this case, the research argument obtained two possibilities that tourists will be more selective in choosing tourist destinations and prioritize domestic destinations over overseas tourist destinations; thus, rising tourism ethnocentrism or the second possibility, more people are becoming more vigilant and avoiding crowds, thus avoiding crowded mass tourist destinations and replacing them with more private or remote tourist destinations. This attitude is referred to as tourism xenophobia, resulting in fewer trips abroad, avoiding ethnic cuisine, and improving group travel and travel insurance.

The third change is in the behavior of citizens. It is possible that citizens also experience tourism xenophobia, where there are unfriendly attitudes in welcoming tourists, although this opinion needs further research. Next is a change in the tourism industry. Directly or not tourism industry is significantly related to the macroeconomic and micro sectors and the health sector as the main base in presenting stability in human mobilization. Therefore, there will be some adjustments made by the government as policymakers and society as the backbone of the micro economy. The fifth or final change in this research is the occurrence of long-term and indirect effects. Many studies have focused only on the direct effects of COVID-19 on the tourism industry, but not much research on the long-term and indirect impact 
of this pandemic. When we talk about sustainability in the tourism industry, it cannot be separated from policy and finance, so there will be many questions about the scale of priorities. The complex situation created is when governments and businesses maintain the current economic system with financial support and deregulation.

On the other hand, society will be pragmatic in assessing the economy's prices instead of seeing a "sustainability". In the event of a recession in the future, many companies in the tourism industry sector previously invested in sustainable tourism development will be more pragmatic in this project. Therefore, we have not been able to see the continued effects of COVID-19 on this industry (Zenker \& Kock, 2020).

In response, the authors agree with the development of e-tourism as an alternative effort in re-living the tourism industry in Indonesia. This alternative effort is in line with research conducted by Gretzel et al. (2020), stating that e-tourism is a scientific discipline that cannot be separated from information technology (IT). Without IT, there will be no tourism during and after the COVID-19 pandemic. IT holds the key to understand the new conditions attached to the deterrent concerning the way people manage to travel with their daily lives and view e-tourism as part of the future both in an absolute term and as part of the research. Moreover, in this paper, (Gretzel et al., 2020) also offer six foundations of change or transformation in understanding e-tourism in the future; including:

1. be aware of the past and the value of continuity (historical);

2. be aware of the factors that influence the creation of knowledge (reflexivity);

3. explicit about its values (transparency);

4. sensitive to the different opportunities to participate in research and the various impacts of its findings (equity)

5. open to a diversity of topics and approaches (plurality); and

6. willing to break down boundaries and be prescriptive (creativity).

These six foundations are not a definite reference in researching e-tourism in the future. However, this research is expected to provide offers to revive the tourism industry during and after the COVID-19 pandemic. High expectations for breakthroughs and innovations toward the development of the tourism industry in the future are not only charged to policymakers, but researchers in tourism should have taken a more role, especially in this unprecedented crisis.

\section{CONCLUSION}

The COVID-19 pandemic has led to the destruction of the economy, the long-term crisis, and the increasingly real threat of global recession. The global economic downturn also has directly or indirectly impacted the tourism industry. Human mobility is the principal capital of tourism moving the transportation sector. Small, medium, and micro-businesses are experiencing appalling conditions, even unprecedented. This condition also applies to the tourism industry in Indonesia. The cessation of the transportation sector's operation, mainly air transportation, has resulted in many airlines suffering losses as they must house most of their pilots and employees. In the hospitality sector, many hotels closed their businesses because of guests' and visitors' absence until the close of tourist destinations, impacting the cessation of tourism's economic drivers, both micro and macro. It was due to the Indonesian government's social restrictions to prevent the transmission and spread of COVID-19 more widely.

After more than three months of strict restrictions on people's social activities, the Indonesian government experienced a much more severe problem: the deterioration of the economy caused by the decrease in public consumption. Realizing this, the Indonesian government took a reasonably risky step by adopting the "new normal" to slowly restore the community's economic activities, especially in the tourism sector, as one of the largest sectors contributing to national economic growth.

Through the Ministry of Tourism and Creative Economy (Kemenparekraf), the government launched a strict health protocol in the face of adaptation of the new normal (new standard) in the industry by launching an operational procedure standard known as the 
CHSE program. Moreover, the development of e-tourism by involving information technology (IT) is an inevitability in facing the digitalization era and innovation and breakthrough during the pandemic and post-pandemic of COVID-19.

Pandemic COVID-19 presents challenges for people's lives globally and opportunities for various changes, especially in the tourism industry sector. This pandemic opens our understanding that the tourism industry must not always rely on crowds and public consumption. However, it can also be presented by developing information technology and digitization while providing space for restoring nature as a tourist destination explored for a long time. Although this opinion has always been a debate for the meaning of ideal sustainability, at least this understanding can be wisdom for the sustainability of the tourism industry in the future.

\section{ACKNOWLEDGEMENT}

This article is part of the research conducted by a team of researchers and authors supported through competency development research schemes of the Institute for Research and Community Development (LPPM) of Universitas Jenderal Soedirman (UNSOED). Therefore, we thank the Chairman of LPPM UNSOED and rector UNSOED, who have allowed us to carry out this research and publish this scientific article.

\section{REFERENCE}

Awirya, A. A. (2020). Dampak Penurunan Kegiatan Pariwisata Terhadap Ketenagakerjaan Di Indonesia.

Arida, I. N. S. (2014). Buku Ajar Pariwisata Berkelanjutan. Sustain-Press 2-86.

Astuti, S. A. (2020). Era Disrupsi Teknologi 4.0 Dan Aspek Hukum Perlindungan Data Hak Pribadi. PAJOUL (Pakuan Justice Journal Of Law), 01(01):1-32.

Badan Pusat Statistik. 2020. Ekonomi Indonesia Triwulan I 2020 Tumbuh 2,97 Persen. Retrieved September 10, 2020, from Badan Pusat Statistik: (https://www.bps.go.id/ pressrelease/2020/05/05/1736/ekonomi-indonesia-triwulan -i-2020-tumbuh-2-97-persen.html).

BBC. (2020). Virus Corona: Sekitar 50 Juta Orang Akan Kehilangan Pekerjaan Di Sektor Pariwisata Akibat Pandemi. Retrieved September 10, 2020 from BBC: (https://www.bbc.com/indonesia/indonesia-51764525).

BBC News Indonesia. (2020). Indonesia 'kritis' Virus Corona:
Target Uji PCR Jauh Dari Standar Minimum Di Tengah Penyebaran Tinggi, 'Banyak Orang Di Luar Terinfeksi Dan Menulari Orang Lain. Retrieved September 10, 2020, from BBC News Indonesia: https://www.bbc.com/indonesia/ indonesia-53393688

Boyd, S. W., \& Butler, R. W. (1996). Managing ecotourism: An opportunity spectrum approach. Tourism Management, 17(8), 557-566.

Brundtland, G. H. (1985). World commission on environment and development. Environmental policy and law, 14(1), 26-30.

Butler, R. (1980). The concept of a tourist area cycle of evolution: Implications for management of resources. Canadian Geographer, 24, 5-12.

Chang, C. L., McAleer, M., \& Ramos, V. (2020). A Charter for Sustainable Tourism after COVID-19. Sustainability (Switzerland) ,12(9).

Choi, H. C., \& Sirakaya, E. (2006). Sustainability indicators for managing community tourism. Tourism management, 27(6), 1274-1289.

Darma, I. G. K. I. P., \& Kristina, N. M. R. (2020). Pemulihan Fungsi Alam Pariwisata Ditengah Pandemi Covid-19. Khasanah IImu-Jurnal Pariwisata Dan Budaya, 11(2), 101-108.

Del Valle, A. S. (2020). The Tourism Industry and the Impact of Covid-19, Scenarios and Proposals. Global Journey Consulting Madrid.

DW. 2020. Bagaimana Sektor Pariwisata Indonesia Bertahan Di Tengah Pandemi Corona. Retrieved September 10, 2020, from DW: https://www.dw.com/id/bagaimana-pariwisataindonesia-bertahan-di-tengah-pandemi/a-54818132

Gretzel, U., Fuchs, M., Baggio, R., Hoepken, W., Law, R., Neidhardt, J., Pesonen, J., Zanker, M. \& Xiang, Z. (2020). e-Tourism beyond COVID-19: a call for transformative research. Information Technology \& Tourism, 22(2), 187-203.

Hardy, A., Beeton, R. J., \& Pearson, L. (2002). Sustainable tourism: An overview of the concept and its position in relation to conceptualisations of tourism. Journal of sustainable tourism, 10(6), 475-496.

Hong, Y., Cai, G., Mo, Z., Gao, W., Xu, L., Jiang, Y., \& Jiang, J. (2020). The impact of COVID-19 on tourist satisfaction with B\&B in Zhejiang, China: an importance-performance analysis. International Journal of Environmental Research and Public Health, 17(10), 3747.

Ikbar, Y. (2014). Metodologi dan Teori Hubungan Internasional. Bandung: Refika Aditama.

International Labour Organization. (2012). Rencana Strategis Pariwisata Berkelanjutan Dan Green Jobs Untuk Indonesia.

Ikbar, Yanuar. 2014. Metodologi Dan Teori Hubungan Internasional. 1st ed. Bandung: Pt Refika ADitama.

Junaidi, I. (2017). Langkah strategis pengembangan indigenous tourism: Studi kasus di Kabupaten Kepulauan Selayar. Masyarakat, Kebudayaan dan Politik, 30(3), 266-277.

Kemenparekraf. (2020). Model Dan Proses Verifikasi Dan Setifikasi CHSE.

Kemenparekraf. (2020). Rencana Strategis KEMENPAREKRAF/ BAPAREKRAF 2020-2024.

Kusumawardhani, A. (2020). Ini 10 Negara Yang Rugi Besar Akibat COVID-19. Retrieved September 10, 2020, from Bisnis: https://ekonomi.bisnis.com/read/20200823/12/1282003 
/ini-10-negara-yang-rugi-besar-akibat-COVID-19

Lew, A. A. (2011). Tourism's Role in the Global Economy. Tourism Geographies 13(1), 148-51

Mcdonald, J. R. (2020). Edith Cowan University. The Grants Register 2021, 344-45.

Metaxas, T, \& Folinas, S. (2020). Tourism: The Great Patient of Coronavirus COVID-2019. Munich Personal RePEc Archive.

Milne, G. J., \& Xie, S. (2020). The Effectiveness of Social Distancing in Mitigating Covid-19 Spread: A Modelling Analysis. MedRxiv.

Ministry of Finance. (2020). Rincian Anggaran Program Pemulihan Ekonomi Nasional (PEN) Sektor Pariwisata.

Ministry of Tourism Republic of Indonesia. (2017). Penghargaan Pariwisata Berkelanjutan Indonesia: Buku Pedoman.

Mutiah, D. (2020). Sektor Pariwisata Nyaris Tumbang Akibat Corona COVID-19, Menparekraf Masih Siapkan Solusi. Retrieved September 10, 2020, from Liputan 6: https://www .liputan6.com/lifestyle/read/4209455/sektor-pariwisatanyaris-tumbang-akibat-corona-COVID-19-menparekraf -masih-siapkan-solusi

Nisa, C. (2020). Strategi Industri Pariwisata Dalam Menghadapi New Normal. Retrieved September 11, 2020, from Kemenparekraf: https://pedulicovid19.kemenparekraf.go.id /strategi-industri-pariwisata-dalam-menghadapi-newnormal/

Pranita, E. (2020). Indonesia Tak Pilih Lockdown Sebagai Solusi, Ini Alasannya. Retrieved September 10, 2020, from Kompas: https://www.kompas.com/sains/read/2020/04/02/ 110000123/indonesia-tak-pilih-lockdown-sebagai-solusi -ini-alasannya-

Rahmat, A. N. (2015). Keamanan Global: Transformasi Isu Keamanan Pasca Perang Dingin. 1st ed. Bandung: Alfabeta.

Revindo, M. D., Sabrina, S. \& Sowwam, M. (2020). Dampak Pandemi COVID-19 Terhadap Pariwisata Indonesia: Tantangan, Outlook Dan Respon Kebijakan Briefing Note.

Ronald. (2020). Ditunjuk Jokowi Sebagai Ketua Gugus Tugas Penanganan COVID-19, Ini Tugas Doni Monardo. Retrieved September 10, 2020, from Liputan 6: https://www.liputan6 .com/news/read/4202052/ditunjuk-jokowi-sebagai-ketuagugus-tugas-penanganan-COVID-19-ini-tugas-doni-monar do

Safriana, L. (2020). New Normal, Peta e-Tourism 4.0 Dan Kemandirian Bangsa. Retrieved September 11, 2020, from Katadata: https://katadata.co.id/redaksi/indepth/5ef9ce654 ac50/new-normal-peta-e-tourism-40-dan-kemandirian -bangsa

Simatupang, V., \& Sukmadi, S. (2020). Analisis Kebijakan Pembangunan Pariwisata Berkelanjutan di Kota Bandung Selama Pandemi Covid 19. Media Bina Ilmiah, 15(6), 4669-4680.

Stoddard, J. E., Pollard, C. E., \& Evans, M. R. (2012). The triple bottom line: A framework for sustainable tourism development. International Journal of Hospitality \& Tourism Administration, 13(3), 233-258.

Sugihamretha, I. Dewa Gde. 2020. "Respon Kebijakan: Mitigasi Dampak Wabah COVID-19 Pada Sektor Pariwisata." The Indonesian Journal of Development Planning IV(2):191-206.

Sugihamretha, I. D. G. (2020). Respon Kebijakan: Mitigasi Dampak Wabah Covid-19 Pada Sektor Pariwisata. Jurnal Perencanaan
Pembangunan: The Indonesian Journal of Development Planning, 4(2), 191-206.

Sumani, N. (2020). Dimensi Kerusakan Ekosistem Hutan Picu COVID-19. In Tadulako Academic Perspective Rona.

Tosun, C. (2000). Limits to community participation in the tourism development process in developing countries. Tourism management, 21(6), 613-633.

UNWTO. (2005). Making Tourism More Sustainable. Retrieved March 15, 2021, from UNWTO: https://www.unwto.org /sustainable-development

UNWTO. (2020). International tourism highlights international tourism continues to outpace the global economy. World Tourism Organisation. Retrieved April 19, 2021, from UNWTO: https://www.unwto. org/international-tourismgrowth-continues-to-outpace-the- -economy

UNWTO. (2020). New Data Shows Impact of COVID-19 on Tourism as UNWTO Calls for Responsible Restart of the Sector.

WHO. (2020). Coronavirus Disease (COVID-19) Weekly Epidemio logical Update Global Epidemiological Situation.

Widodo, W. S. (2020). Disiplin, Kunci Dunia Pariwisata Hadapi Era New Normal. Retrieved September 11, 2020, from Detik: https://travel.detik.com/travel-news/d-5038445/disiplinkunci-dunia-pariwisata-hadapi-era-new-normal

Winarno, B. (2011). Isu-Isu Global Kontemporer. Yogyakarta: CAPS.

World Bank. (2020). 2020 Year in Review: The impact of COVID-19 in 12 charts. Retrieved Marh 15, 2021, from World Bank: https://blogs.worldbank.org/voices/2020-year-reviewimpact-covid-19-12-charts

Zenker, S., \& Kock, F. (2020). The coronavirus pandemic-A critical discussion of a tourism research agenda. Tourism management, 81, 104164. 